\title{
Evaluation of athlete burnout among elite coaches and its relationship with mental health
}

\author{
Mir Hamid Salehian', Abdollah Hemayat Talab ${ }^{2}$, Abolfazl Neshati ${ }^{2}$, Esmaeil Qiyomarsi ${ }^{3}$ \\ 1-Assistant Professor, Department of Physical Education, Tabriz Branch, Islamic Azad University, Tabriz, Iran \\ (Corresponding Author). $\quad$ E-mail: M_salehian@iaut.ac.ir \\ 2- Assistant Professor, Department of Physical Education, Marand Branch, Islamic Azad University, Marand, Iran. \\ 3- MSc, Department of Physical Education, Urmia University of Technology, Urmia, Iran.
}

Received: 08/11/2021 Accepted: 10/01/2022

\begin{abstract}
Introduction: In recent decades, the interest in assessing, monitoring, and improving physical and mental health has increased significantly, so that improving physical and mental function has been considered a vital goal globally.

Aim: The evaluated the athlete burnout among elite coaches and its relationship with mental health.

Method: The research is correlational. The population was professional male coaches in the super leagues of Basketball, Handball, Volleyball, Futsal, and Wrestling in 2021. According to the statistics of the relevant federations, there were 247 coaches and head coaches. After distributing and collecting research questionnaires, 241 people completely answered the questionnaires. Ryff Scales of Psychological Well-Being (18-item) and Athlete Burnout Questionnaire were used to collect research data. Data were analyzed using SPSS software version 20.

Results: The results showed a negative and significant relationship between athlete burnout and the mental health of coaches. The results of multivariate regression analysis confirmed the inverse relationship between the components of Athlete burnout and mental health. Information related to the goodness of fit index showed that the correlation coefficient $(0.361)$ and the coefficient of determination (0.130) indicate the fitness of the evaluated model. In other words, the relationship between predictor and criterion variables was $36.1 \%$.
\end{abstract}

Conclusion: Due to the negative effects of burnout on psychological health, it is suggested to coaches to consider the psychological injuries caused by the pressure of training and competitions and pay special attention to them as factors related to reducing mental health.

Keywords: Health, Coaches, Athlete burnout

How to cite this article: Salehian MH, Hemayat Talab A, Neshati A, Qiyomarsi E. Evaluation of athlete burnout among elite coaches and its relationship with mental health. Shenakht Journal of Psychology and Psychiatry. 2022; 8 (6): 114-124 .URL: http://shenakht.muk.ac.ir/article-11366-en.pdf

Copyright $(\odot 2018$ the Author (s). Published by Kurdistan University of Medical Sciences. This is an open access article distributed under the terms of the Creative Commons Attribution-Non Commercial License 4.0 (CCBY-NC), where it is permissible to download, share, remix, transform, and buildup the work provided it is properly cited. The work cannot be used commercially without permission from the journal. 


\title{
ارزيابى تحليل رفتكى مربيان نخبه كشور و ارتباط آن با سلامت روانشناختى
}

\author{
ميرحميد صالحيان '، عبداله حمايت طلب '، ابوالفضل نشاطى '، اسماعيل كيومرثى

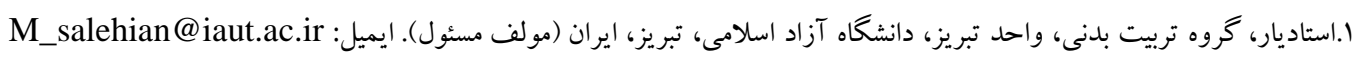 \\ r. استاديار، گروه تربيت بدنى، واحد مرند، دانشكاه آزاد اسلامى، مرند، اير آندان. \\ r. كارشناس ارشد، گروه تربيت بدنى، دانشكاه صنعتى اروميه، اروميه، ايران.
}

مقدمه: در طول جند دهه اخير، علاقه به ارزيابى، بيگيرى و بهبود سلامت جسمانى و روانشناختى افراد افزايش جشمخيرى يافته،

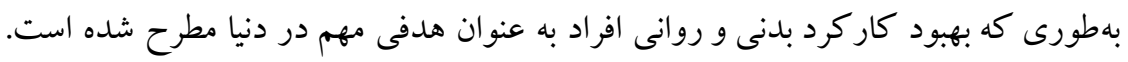
هدف: يزوهش حاضر با هدف ارزيابى تحليل رفتكى مربيان نخبه كشور و ارتباط آن با سلامت روانشناختى انجام شد. روش: روش يُزوه حاضر از نوع تحقيقات همبستگى است. جامعه آمارى يزوهش حاضر را كليه مربيان مرد حرفهاى ليگكاى برتر

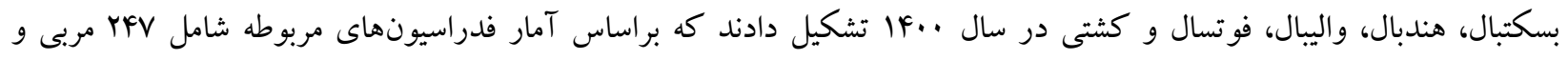

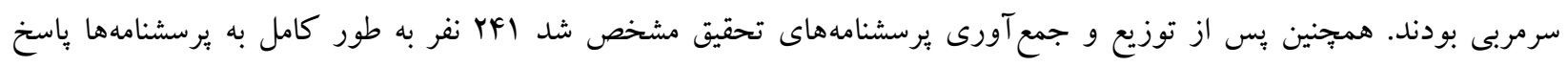

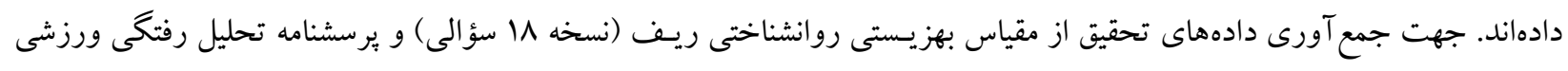
استفاده شد. دادهها با استفاده از نرمافزار SPSS نسخه ·r ت تحليل شد. يافته ها: نتايج نشان داد بين ميزان تحليل رفتخى ورزشى با سلامت روانشناختى مربيان ارتباط منفى و معنادارى وجود دارد. نتايج آزمون

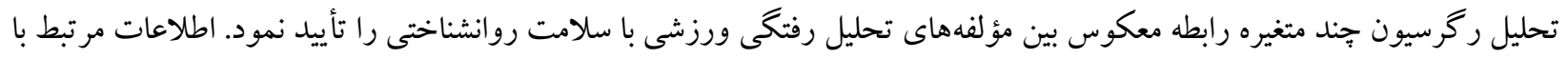

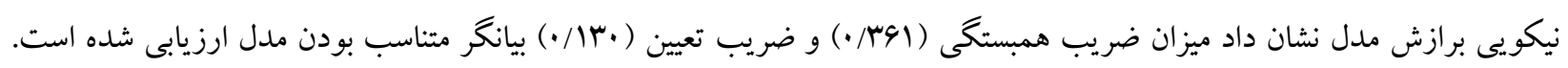

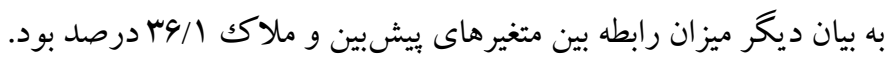

نتيجه كيرى: با توجه به اثرات منفى تحليل رفنكى ورزشى بر سلامت روانشناختى به مربيان بيشنهاد مىشود آسيبهاى روانشناختى كه

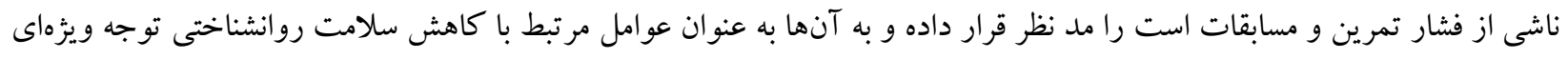

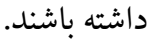
كليدوازهها: سلامت، مربيان، تحليل رفتخى ورزشى 
همكاران، .Y.Y.Y)؛ لذا وضعيت سلامت روانى افراد يكى مقدمه از موضوعات مهم در هر جامعه محسوب مىشود و بايد به طور منظم و هدفمند، ارزيابى آن در دستور كار

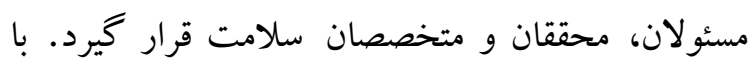
توجه به اينكه جسم و روان به طور متقابل بر يكديخر

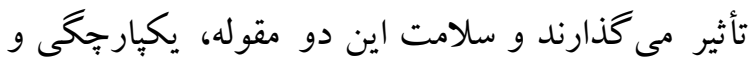

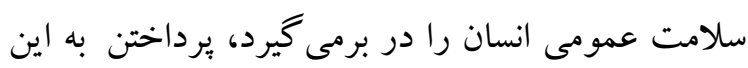
موضوع و شناخت تأثيرات دائمى اين دو بر يكديخر از ضروريات است (واعظ موسوى و شمس، وهب1). نتايج مطالعات نشان مىدهند به طور كلى ||-ه / | درصد بار كلى بيمارىها به بيمارىهاى روانى مرتبط است و با محاسبه سالهاى تقريبى ناتوانى در طول عمر اين رقم به

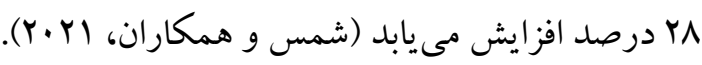
از سوى ديخر اغلب بزوهشهاى اخير در قلمرو بررسى

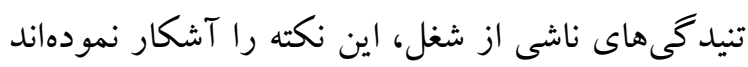

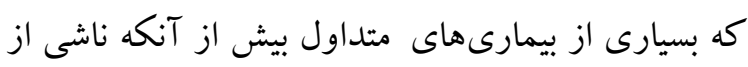
عوامل ميكروبى و ويروسى باشند بر اثر فقدان سازش با محيط كار و ايجاد فشار و استرس به وجود ميى آيند (احمدى و همكاران، سوسا). در اين ميان مربيخرى به عنوان شغلى تعريف مىشود كه متغيرهاى استرسزاى زيادى ماند برخوردهاى ناشايست طرفداران و مسئولين باشگاهها در ارتباط با نتايج بدست آمده، فشارهاى غيرمعقول باشگاه براى بردن بازى و كسب امتياز، عدم حمايت كافى از جانب باشگاه و مصدوميت بازيكنان كليدى گروه بر آن حاكم است (كاراباتوس و نيكلاس بـ"

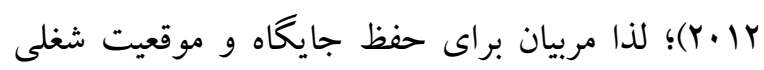
خود بايد اين فشارها و استرسها را تحمل نموده و زمان زيادى را براى آمادگى گروه خود و و شناسايى نقاط

${ }^{3}$ - Karabatsos \& Nikolaos

1- Mental health

${ }^{2}$ - World Health Organization (WHO) 
نيكسدورف (Y.Y.(Y. نيز اظهار نمودند عوامل سازمانى تأثير بسزايى در فرآيند تحليل رفتكى دارند و اين فرآيند براى سازمانها يكك بِيده هزينهبر است. براساس

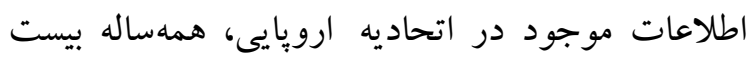

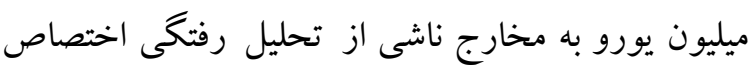

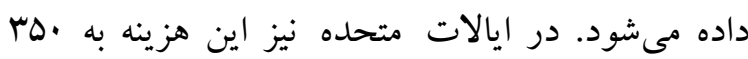

$$
\text { ميليون دلار در هر سال مىرسد. }
$$

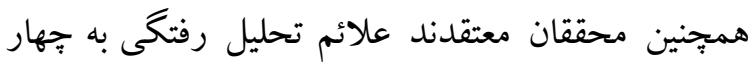
دسته علائم جسمانى، علائم هيجانى و روانى، علائم اجتماعى و علائم سازمانى تقسيم مىشود (نيكسدورف و

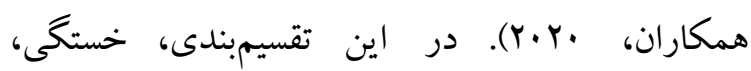
مشكلات خواب، مشكلات جسمانى و مشكلات تغذيه،

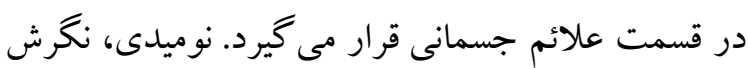
منفى نسبت به خود، تغييرات خلقى، كاهش تحمل، افسردگى، كاهش سلامت روانى و علائمى از اين قبيل نيز در قسمت علائم هيجانى و روانى جاى دارد. گسستخى ارتباطى، گوشه گيرى، بدبينى نسبت به مردم و درگيرى با اعضاى خانواده، در قسمت علائم اجتماعى و غيبت از كار و بازدهى اندك و نكخرش منفى به كار در قسمت علائم سازمانى قرار مى گيرند. بر اين اساس در

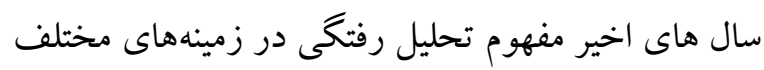
ورزشى مورد بررسى قرار گرفته است. به طور كلى مطالعات انجام شده در اين زمينه جندين مدل را ماند مدل استرس عاطفى- شناختى، مدل بِاسخ منفى به تمرين - استرس و مدل رشد تكك بعدى هويت و كنترل بيرونى را ارائه نمودهاند (او كلوند و دفريس، YV) مدلهاى ارائه شده همكى بر اين كه نكته اذعان داشتهاند كه استرس و فشارهاى روانى نقش بسيار مهم و تعيين

\footnotetext{
${ }^{6}$ - Nixdorf, Beckmann \& Nixdorf
}

ضعف و قوت حريفان صرف نمايند (نافيان، مرداى و

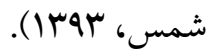
استرسهاى ناشى از شغل نوعى فشار روانى محسوب مىشوند و تأثير منفى بر زندگى فردى، اجتماعى و خانوادگى فرد مى گذارند. روانشناسان حوزه مديريت يكى از عوارض فشارها و استرسهاى ناشى از شغل را

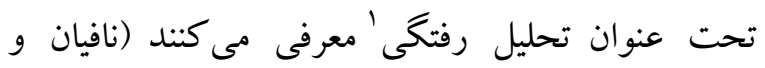
همكاران، سوسا). آنها معتقدند تحليل رفتخى شامل رلى ياسخهايى است كه آدمى در برابر فشارهاى روانى از

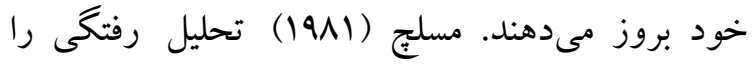
نوعى سندروم روانشناختى تعريف كرده است كه شامل عو امل فرسودكى عاطفى '، مسخ شخصيت ' (تهى شدن از

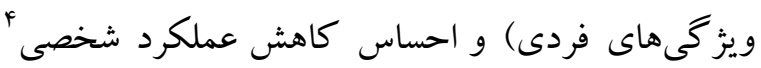
است. وى معتقد است اين سندروم بيشتر در ميان متخصصانى كه در موقعيتهاى جالشبرانگيز، با افراد ديخر كار مى كنند، اتفاق مىافتد (به نقل از نافيان و

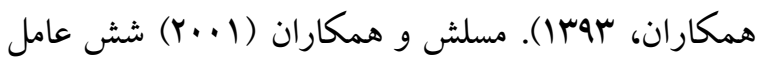
سازمانى را معرفى نمودند كه در ايجاد تحليل رفتكى داراى اهميت بسيارى هستند. اين عوامل شامل حجم كار كم يا زياد، ميزان كنترل كم بر كار، ياداش كم، نداشتن ارتباط اجتماعى تبعيض در محيط كار، تضاد بين ارزشهاى فرد و محيط كار هستند (به نقل از نافيان و

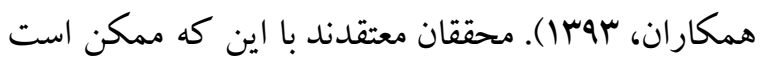
تحليل رفتخى در هر شغلى و حرفهاى رخ دهد؛ اما يكك مشكل و بيمارى مسرى شايع جهانى محسوب مى شود

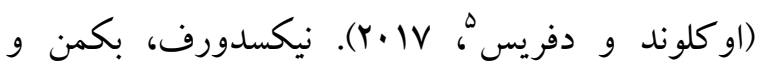

\footnotetext{
1- Burnout

2- Emotional Exhaustion

3 - Depersonalization

4- Self-Accopmlishment

5 - Eklund \& Defreese
} 
يثوهش حاضر با توجه به هدف كاربردى و براساس روش جمع آورى اطلاعات در زمره تحقيقات توصيفى و از نوع تحقيقات همبستخى قرار دارد. جامعه آمارى يزّوهش حاضر را كليه مربيان مرد حرفهاى ليگكهاى برتر بسكتبال، هندبال، واليبال، فوتسال و كشتى در سال . 1F تشكيل دادند. براساس آمار فدراسيونهاى مربوطه شامل ه9) (مFV مربى و سرمربى به تفكيك در رشته هاى واليبال

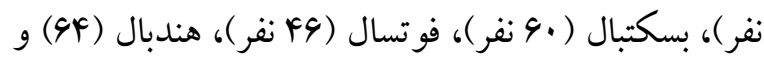
كشتى (I نفر) بودند. براى اطمينان از عدم ريزش نمونها و تأثير گذارى آن بر نتايج تحقيق تمامى جامعه آمارى به عنوان نمونه آمارى در نظر كرفته شد. همجينين يّ از توزيع و جمع آورى برسشنامهاى تحقيق مشخص شد YFI نفر به طور كامل به برسشنامهها ياسخ دادهاند. معيارهاى ورود به مطالعه شامل داشتن مدرك مربى گرى

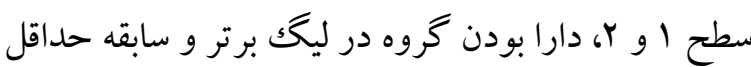
ه سال مربى گرى بود. معيارهاى خروج نيز شامل عدم

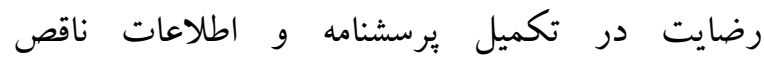
يرسشنامهها بود. يس از اخذ مجوز از فدراسيونهاى منتخب، جهت جمع آورى دادههاى مورد نياز، تعدادى از برسشنامههاى تهيه شده، حاوى نكات لازم در خصوص بزوهش و محرمانه بودن اطلاعات شخصى آزمودنى ها، به دليل بعد مسافت و

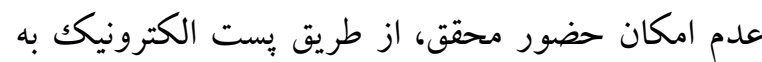
آدرس هاى بِت الكترونيك آنها ارسال شد و يِيَيرى -

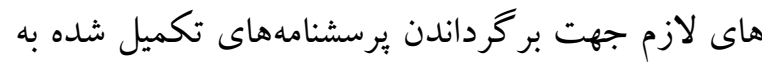
صورت تماس تلفنى انجام شد. بقيه برسشنامها توسط "يخوهشكران، به دليل امكان دسترسى آسان و سهولت در توزيع و صرفهجويى در زمان، به صورت حضورى به مربيان و سرمربيان گروهها تحويل داده شد. در اين مرحله

كننده در بروز نشانهاى تحليل رفتكى دارند (نافيان و

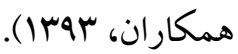
بر اين اساس، كاراباتوس و نيكلاس (Y (Y. در مطالعهاى كه روى مربيان دو و ميدانى يونان انجام دادند، دريافتند كه فشارهاى زياد ناشى از رقابت در سطح بالا منجر به بروز نشانهاى تحليل رفتخى مىشود و در نهايت اين امر منجر به كاهش سطح سلامت روانى و افزايش استرس و افسردگى در آنها مىشود. محققان در مطالعات خود دريافتند هرجه سطح مربيخرى بالاتر باشد، افزايش نشانههاى تحليل رفتگى و استرس و كاهش سلامت روانى و جسمانى بارزتر است (نيكسدورف و همكاران، ·r.r).

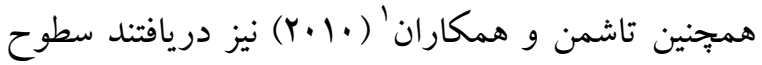
تحليل رفتكى در مربيان به طور مستقيم با استرس و افسردگى آنها در ارتباط است كه اين امر نيز به نوبه خود بر سلامت روان آنها اثرات منفى برجاى مى كذارد. محققان سندروم تحليل رفتكى را به عنوان فرسايش روان انسان توصيف مى كنند. نتايج مطالعات انجام شده در اين زمينه نيز نشان دادهاند كه تحليل رفتكى بيامدهاى فيزيولوزيكى و روانشناختى فراوانى به همراه دارد به طورى كه باعث افزايش خطر ابتلا به بيمارىهاى قلبى عروقى، تخريب عملكرد ايمنى بدن و التهاب مزمن مىشود (نافيان و همكاران، سوسب)؛؛ لذا با توجه به بيامد استرسهاى ناشى از كار در مربيان ورزش كشور و نتايج مطالعات انجام شده، هدف از تحقيق حاضر ارزيابى تحليل رفتكى مربيان نخبه كشور و ارتباط آن با سلامت روانشناختى بود.

\footnotetext{
1. Tashman et al.
} 


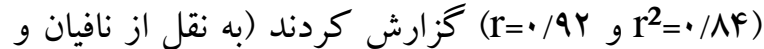
همكاران، سوس|). در ايران اين يرسشنامه توسط احمدى و همكاران (Faץ (I) اعتباريابى شده است. نتايج اين مطالعه نشان داد مقياس تحليل رفتخى با سه عامل، ه ه درصد واريانس كل سؤالات را تبيين نمود. در ارتباط با همسانى درونى سؤالات هر خرده مقياس، ضريب پايايى واماندگى

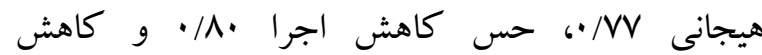
ارزشمندى در ورزش rA| • بود. مقياس بهزيستى روانشناختى ريسف (RSPWB): ريسـف ايسن مقيـاس را در سـال ·191 طراحسى نمـود. فرم اصلى داراى • Y سـؤال بود؛ اما در بررسىهـاى بعدى

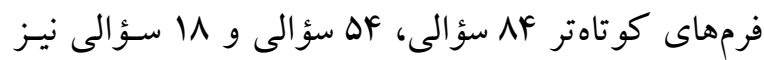
ارائه شد. در ايسن يـزوهش فرم \ل سؤالى آن استفاده شد. مقيـاس بهزيستى روانشناختى داراى شش خرده مقيـاس است. در فرم \1 سـؤالى هـر عامـل داراى ب سـؤال در

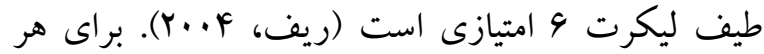
سؤال، امتياز يـك تـا شـش داده مسىشـود. نمره بالاتر بيانگر بهزيستى روانشناختى بهتر است. گيلز و همكاران

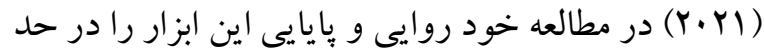
قابل قبول گزارش نمودند. شمس و همكاران (Y.Y.) روايى و يايايى اين مقياس را مورد بررسى قرار دادند و نتايج اين مطالعه نشان داد ضريب پيايايى بدست آمده براى هر مؤلفه بالاتر از 91/. و براى كل مقياس ه9/.

$$
\text { بود. }
$$

\section{يافتهها}

نتايج نشان داد ميانگين سنى مربيان در رشته واليبال برابر با

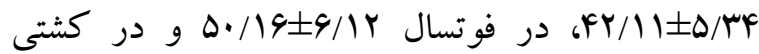

هريكك از برسشنامهها به آنها تحويل داده شد تا شخصاً آنها را تكميل نمايند. در نهايت ملاحظات اخلاقى شامل احترام به حقوق افراد، رضايت آكاهانه و رازدارى اطلاعات در يُزوهش حاضر رعايت شد. تحليل دادهها با استفاده از شاخصهاى آمار توصيفى نظير ميانگين و انحراف استاندارد و روشهاى آمار استنباطى نظير ضريب همبستگى بيرسون (جهت تعيين رابطه بين

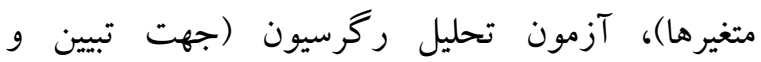
بيشبينى سلامت روانشناختى از مؤلفههاى تحليل رفتخى) انجام شد. همجِين از آزمون كولمو گروف-اسميرنف براى بررسى وضعيت طبيعى بودن توزيع و آزمون لوين براى بررسى تجانس واريانسها استفاده شد. در نهايت تمامى دادهها با استفاده از نرمافزار SPSS نسخه •ب مورد تجزيه و تحليل قرار كرفتند.

ابزار

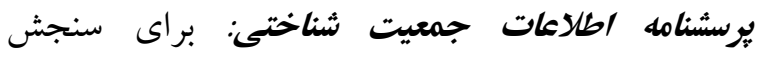
ويز گىهاى جمعيت شناختى مربيان نظير سن، وضعيت تأهل، ميزان تحصيلات، سابقه مربيخرى و سابقه قهرمانى از اين برسشنامه استفاده شد. برسشنامه تحليل رفتكى ورزشى' (ABQ): اين يرسشنامه حاوى ها سؤال است كه سه خرده مقياس را اندازه گيرى مى كند. اين پرسشنامه توسط رادك و اسميت به زبان انگليسى در آمريكا طراحى و در بين ^•• ورزشكار

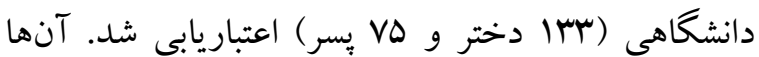

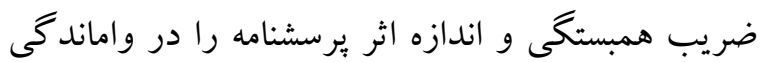

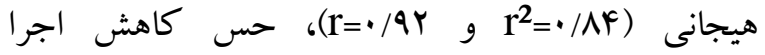

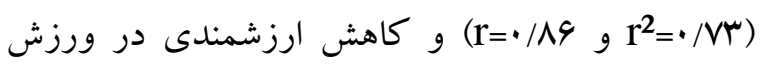

\footnotetext{
1. Athlete Burnout Questionnaire (ABQ)
} 
تحصيلات دكترى تخصصى، كارشناسى ارشد، ·r درصد كارشناسى و سم درصد نيز دييلم بودند. نتايج توصيفى مربوط به متغير سلامت

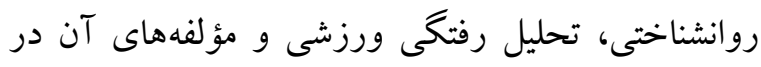
جدول ا ارائه شده است.
برابر با FY/90 $\pm V / 91$ بود. همجنين نتايج مربوط به وضعيت تأهل مربيان نشان داد بيشترين تعداد افراد متأهل مربوط به رشته واليبال (با V V لوصد) و كمترين تعداد مربوط به رشته فوتسال (با FN درصد) است. نتايج مربوط به ميزان تحصيلات مرييان نشان داد ب درصد داراى

\begin{tabular}{|c|c|c|c|c|c|}
\hline كاهش ارزشمندى & شى و كؤلفها: & واماندكى رسم & تحليل رفتكى & سلامت & \\
\hline در ورزش & اجرا & هيجانى & ورزشى & روانشناختى & رشتههاى \\
\hline ميانگين & ميانگين & ميانغين & ميانغين & ميانغين & ورزشى \\
\hline (انحر اف معيار) & (انحراف معيار) & (انحراف معيار) & (انحر اف معيار ) & (انحر اف معيار) & \\
\hline$r \cdot / r Y \pm(r / I V)$ & $|q /| r \pm(\varphi / \mid \Lambda)$ & $r r / Y F \pm(1 / 19)$ & $F Y / V I \pm(Y / \Delta I)$ & $r F / Y r \pm(Y / V \Lambda)$ & واليبال \\
\hline $1 / / 9 \Delta \pm(F / 11)$ & $|r / Y| \pm(r / F \Delta)$ & $|V / 1| \pm(Y / V \varphi)$ & $F N / Q V \pm(F / F F)$ & $r \wedge / \sim q \pm(F / q))$ & بسكتبال \\
\hline$Y Y / 11 \pm(Y / \Gamma Y)$ & $19 / 1 Y \pm(Y / T Y)$ & $r \cdot / r Y \pm(1 / r \Delta)$ & $\Delta V / \Delta \Delta \pm(9 / \cdot 1)$ & $r|r| \pm(\Delta / I I)$ & فوتسال \\
\hline $19 / \cdot 1 \pm(\Delta / / \Lambda)$ & $|r / Y| \pm(F / \mid F)$ & $\mid V / Q \Lambda \pm(Y / \Delta Y)$ & $F V / r \cdot \pm(F / \cdot 1)$ & $r q / r \mid \pm(F / \kappa r)$ & كشتى \\
\hline $19 / \cdot r \pm(\boldsymbol{F} / \widetilde{T})$ & $11 / \cdot V \pm(r / N Y)$ & $|F /| q \pm(Y / \mu q)$ & $\kappa Y / Y \Delta \pm(r / F V)$ & $F Y / Y \mid \pm(\Delta / G Y)$ & هندبال \\
\hline
\end{tabular}

كرفت. نتايج آزمون همبستگى بيرسون آزمون نشان داد

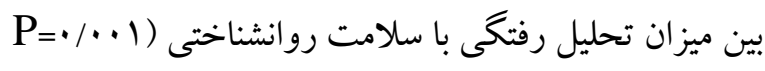

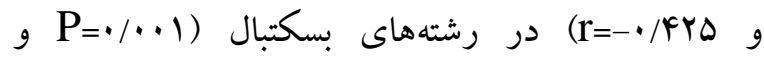
هندبال - • P M $\mathrm{P}=\cdot / \cdot q)$ و كشتى (r= $)$ معنادارى وجود دارد. همجينين نتايج آزمون همبستخى

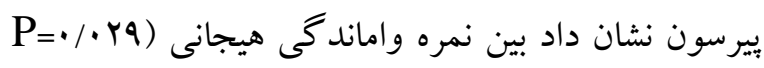

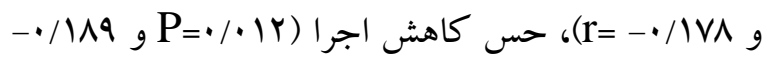

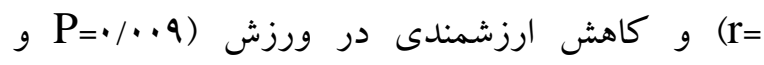

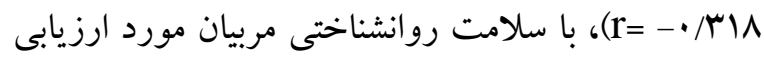
ارتباط منفى و معنادارى وجود دارد. به طور كلى داشتن ارتباط منفى و معنادارى بين ميزان تحليل رفتخى و و سلامت روانشناختى بدين معنا است كه با افزايش ميزان تحليل رفتخى مربيان، ميزان سلامت روانشناختى آنها
براساس اطلاعات اين جدول، مربيان رشته واليبال نسبت به رشتههاى ديخر داراى نمرات بالاترى در متغير تحليل

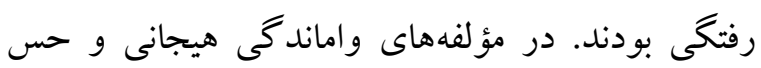
كاهش اجرا نيز مربيان واليبال داراى نمرات بالاترى نسبت به مربيان ديخر بودند. در مؤلفه كاهش ارزشمندى در ورزش نيز مربيان رشته فوتسال داراى نمرات بالاترى نسبت به رشتهاى ديخر بودند. نتايج توصيفى مربوط به متغير سلامت روانشناختى نشان داد مربيان رشته كشتى نسبت به رشتههاى ديخر داراى نمرات بالاترى در متغير سلامت رو انشناختى بودند. جهت بررسى نرمال بودن توزيع نمرات بهزيستى روانشناختى، تحليل رفتكى و مؤلفههاى آن از آزمون برني كالمو گروف -اسميرنف استفاده شد. نتايج نشان داد براى تمامى متغيرهاى مورد مطالعه سطح معنادارى بيشتر از هـ/· است؛ بنابراين توزيع نرمال آنها مورد تائيد قرار 
تحليل رگرسيون به روش ورود استفاده شد كه نتايج در كاهش و با كاهش ميزان تحليل رفتكى ميزان سلامت جدول ب ارائه شده است.

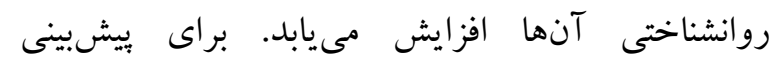

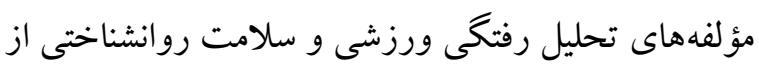

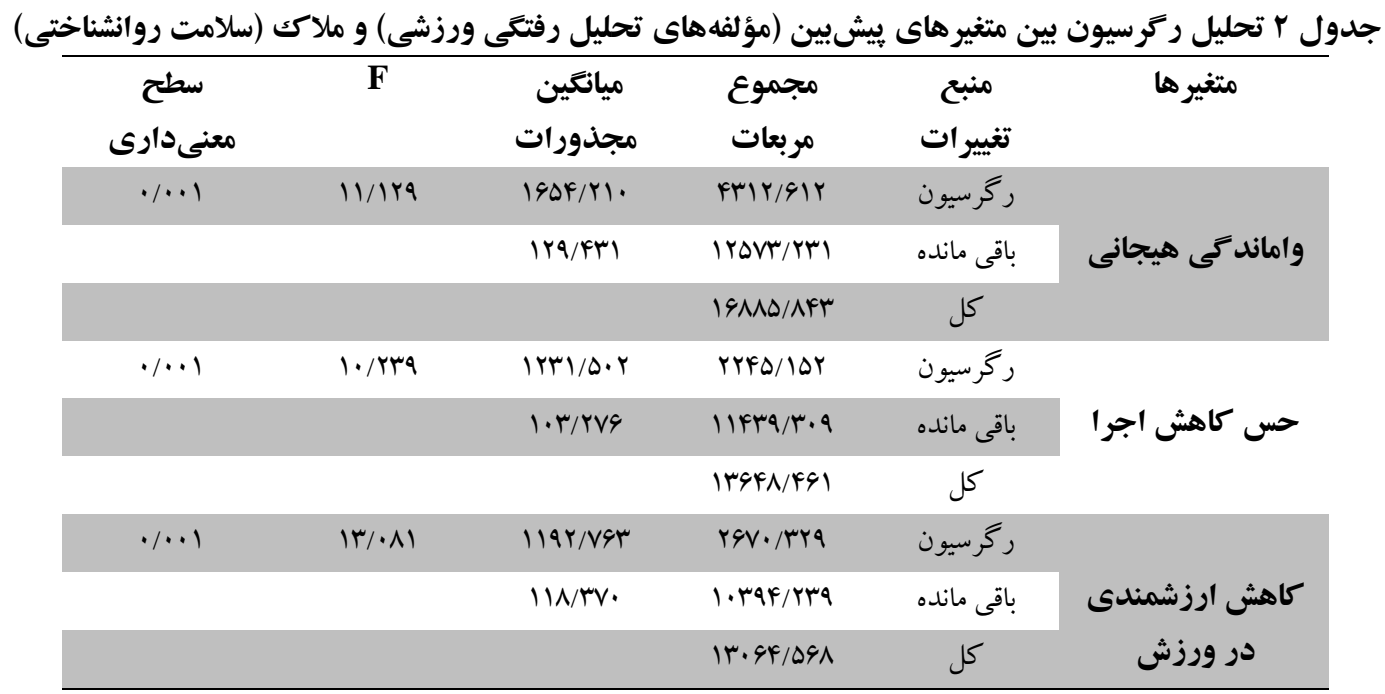

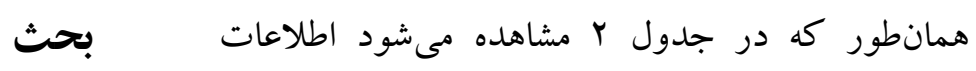

يثوهش حاضر با هدف بررسى ارزيابى ميزان تحليل رفتخى مربيان و ارتباط آن با سلامت روانشناختى انجام شد. نتايج نشان داد بين ميزان تحليل رفتخى ورزشى با

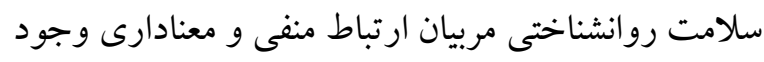

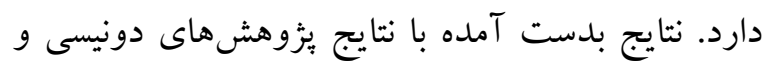

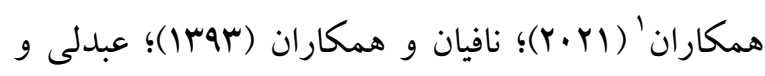

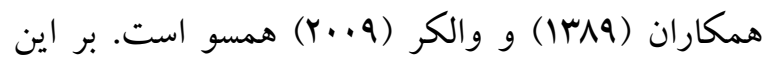
اساس، محققان به بررسى ميزان تحليل رفتكى مربيان و

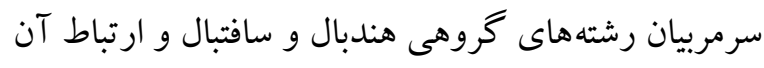
با متغيرهاى استرس ادراكك شده و ميران خود كار آمدى آنها برداختند. نتايج نشان داد مربيان در اين سطح از رقابت داراى ميزان تحليل رفتكى بالايى هستند به طورى لرى كه تحليل رفتگى مربيان ارتباط منفى و معنادارى با ميزان مرتبط با نيكويى برازش مدل و يا تناسب مدل نشان داد ضريب همبستخى اوس/· و ضريب تعيين •بر/. بيانگر متناسب بودن مدل ارزيابى شده است. اين اطلاعات بيانكر اين است كه ضريب همبستگى بين ارزشهاى

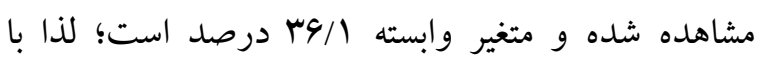
تو جه به مقدار ضريب همبستگى مى توان كفت كه رابطه خطى نسبتاً قوى بين متغيرهاى بيشبين و ملاكك وجود

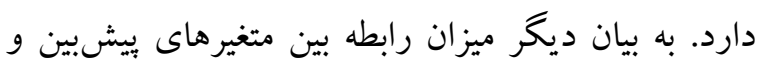

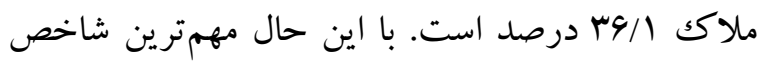
براى برازش و نيكويى مدل ضريب تعيين است. اين ضريب ميزان تناسب و ساز گارى مدل را نشان مىدهد. اين مفهوم بدين معنا است كه متغيرهاى بيشبين سري درصد از تغييرات سلامت روانشناختى را تعيين مى كنند.

\footnotetext{
1- Donisi et al.
} 
شيوه زندگى تا حد بسيار زيادى مىتواند باعث افزايش كار آيى و استقلال افراد شود و به به آنها در كنترل عوارض متعدد و درمانهاى مختلف كمكك نمايد.

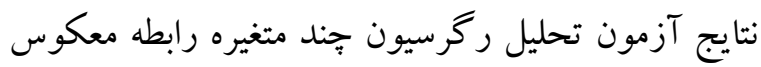
بين مؤلفه هاى تحليل رفتخى ورزشى با سلامت روانشناختى را تأييد نمود و مى توان نتيجه گرفت كه اين مؤلفه ها، سلامت روانشناختى مربيان را بيشبيشى مى كنند. نتايج بدست آمده با نتايج بيزوهشهاى نافيان و همكاران

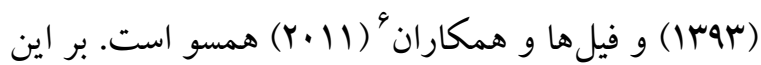
اساس، فيلها و همكاران (YII) اظهار نمودند اگرجهه مؤلفه كاهش عملكرد شخصى ارتباط معنادارى با تحليل رفتخى نداشت و قادر به بيشبينى آن نبود؛ اما مؤلفهاى

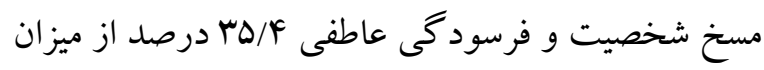

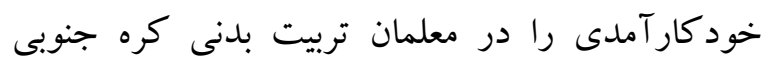

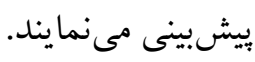
بر اين اساس، كاراباتوس و نيكلاس (Y (Y.Y) مطالعهاى را روى مربيان دو و ميدانى يونان انجام دادند. در اين مطالعه ميزان تحليل رفتكى مربيان و ارتباط آن با متغيرهاى استرس و خود كار آمدى مورد بررسى قرار گرفت. نتايج اين مطالعه نشان داد مؤلفهاى كاهش عملكرد شغلى و مسخ شخصيت توانايى بيشبينى ب// دورصد از ميزان خود كار آمدى را در مربيان دو و ميدانى دارند. همجينين در مطالعه ديخرى اورز و همكاران (Y......) اظهار نمودند

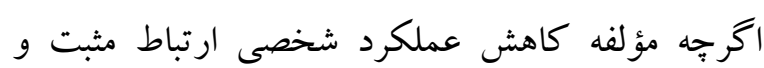

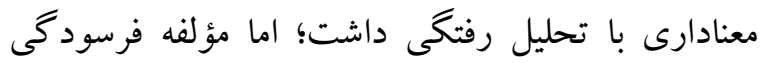
rF/V. عاطفى YQ/AY درصد و مؤلفه مسخ شخصيت درصد از ميزان خود كارآمدى بيشبينى مىنمايند. محققان معتقدند با اين كه ممكن است تحليل رفتكى در

${ }^{6}$ - Pil Ha et al.
خود كار آملى و ارتباط مثبت و مستقيمى با استرس داشت. به طور كلى داشتن ارتباط منفى و معنادارى بين ميزان تحليل رفتكى ورزشى و مؤلفهاى آن با سلامت روانشناختى در بززوهش حاضر بدين معناست كه با افزايش ميزان تحليل رفتخى مربيان ميزان سلامت روانشناختى آنها كاهش مى يابد (به نقل از نيكسدورف مريفي

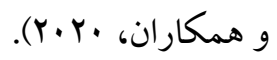
در ساليان اخير رويكرد آسيب شناختى به مطالعه سلامتى انسان مورد انتقاد قرار گرفته است. بر خلاف اين ديدگاه كه سلامتى را به عنوان نداشتن بيمارى تعريف مى كند، رويكردهاى جديد بر "(بزيستى)" به جاى ("بد يا بيمار

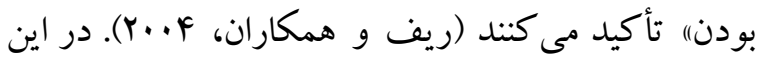
ديدگاه نبود نشانهُ بيمارىهاى روانى، شاخص سلامت فيد نيست، بلكه ويزگى هاى روانشناختى مثبت شامل ساز گارى، شادمانى و نشاط، اعتماد به نفس و رضايت از زندكى نشان دهنده سلامت بوده و هدف اصلى فرد در زندگىى، شكوفا سازى قابليتهاى خود است (برسل،

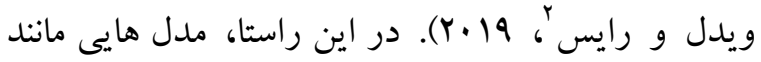
مدل جاهو دا'، مدل بهزيستى ذهنى دينر وّ مدل شش عاملى بهزيستى روانى ريف، تدوين شدهاند كه در تعريف و تبين سلامت روانى به جاى تمركز بر بيمارى و ضعف بر توانايىها و داشتهاى فرد متمركز هستند (شمس و همكاران، (Y.Y.). از سوى ديخر، محققانى

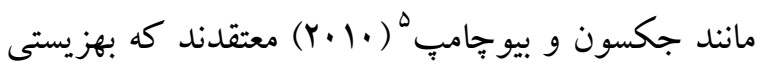
روانى ارتباط بسيار نزديكى با كيفيت زندكى افراد دارد. براساس نظر شمس و همكاران (Y.Y.Y.) توجه به كيفيت زندگى و تأثير ملاحظات مختلف روانشناختى و اصلاح

\footnotetext{
1. Wellness

2- Purcell, Gwyther \& Rice

3 - Jahoda

4- Diener subjective well-being model

5- Jackson \& Beauchamp
} 
شماره مار/

افراد شركت كننده در بزُوهش كمال تشكر و قدردانى را

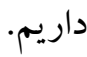

\section{References}

Abdoli B, Shamsipour Dehkordi P, Shams A. (2009). The Interactive Role of Physical Activity and Personality Traits in Psychosocial Status of Elders. Salmand: Iranian Joumal of Ageing, 4(1):7-15. (In Persian)

Ahmadi N, Abdoli B, Ariafar M. (2014). Psychometric Properties of Persian Version of the Athlete Burnout Questionnaire (ABQ) in Athletes. Sport Psychology Studies, 3(9):102-93. (In Persian)

Aslankhani MA, Farokhi A, Shamsipour Dehkordi P, Shams A, Ghasemian Moghaddam MR. (2010). The Relation of Personality Traits with Depression Severity in Active and NonActive Elderly Women in Tehran City. Salmand: Iranian Joumal of Ageing, 5(2):4653. (In Persian)

Donisi V, Tedeschi F, Gonzalez-Caballero JL, et al. (2010). Is Mental Well-Being in the Oldest Old Different from That in Younger Age Groups? Exploring the Mental Well-Being of the Oldest-Old Population in Europe. J Happiness Stud, 22, 1693-1717.

Eklund RC, Defreese JD. (2017). Athlete bumout: what we know, what we could know, and how we can find out more. Intemational Journal of Applied Sports Sciences, 27(2):6375.

Giles S, Fletcher D, Amold R, et al. (2020). Measuring Well-Being in Sport Performers: Where are We Now and How do we Progress?, Sports Med 50,1255-1270.

Jackson B, Beauchamp R. (2010). Self-efficacy as a Meta perception within coach-athlete and athlete-athlete relationships. Psychology of Sport and Exercise, 11(1):188-196.

Karabatsos G, Nikolaos A. (2012). An Investigation of a Model of Personal-Situational Factors, Stress and Bumout in Track and Field Coaches.

$$
\begin{aligned}
& \text { هر شغلى و حرفهاى رخ دهد؛ اما يكك مشكل و بيمارى } \\
& \text { مسرى شايع جهانى محسوب مىشود (به نقل از نافيان و }
\end{aligned}
$$

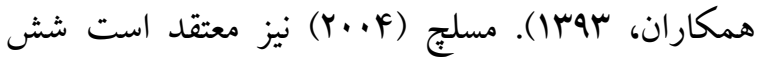

$$
\begin{aligned}
& \text { عامل عمده و مؤثر در ايجاد تحليل رفتگى وجود دارند } \\
& \text { كه شامل باركارى زياد، فقدان كنترل، فقدان پِاداش، } \\
& \text { نداشتن حمايت اجتماعى و عدالت و در نهايت تعارض } \\
& \text { ارزشها مىباشند؛ لذا محققان اظهار نمودند دو عامل } \\
& \text { بار كارى زياد و فقدان ياداش داراى ارتباط بسيار بالايى با } \\
& \text { تحليل رفتگى در مربيان هستند. }
\end{aligned}
$$

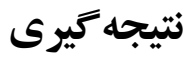

براساس نتايج مطالعه حاضر ضمن آن كه خلأ اطلاعاتى موجود درباره ميزان تحليل رفتكى مربيان كشور و سلامت روانشناختى آنان را بر مى كند، با فراهم كردن دانش پايه در زمينه ارتباط عنصر رفتارى ورزش / فعاليت بلدنى با متغيرهاى روانشناختى دخيل در زندگى سالم، دركى روشنترى از شرايط فعلى سلامت روان مربيان كشور را فراهم مى آورد؛ لذا اين دركك ايجاد شده از رابطه متغيرهاى دخيل در زندگى سالم، ضمن ارضاى حس كنجكاوى علمى دانش بثزوهان، آنان را به ايجاد راهبردهاى ارتقاء شرايط موجود تشويق خواهد نمود و سياست گذاران اجتماعى با تكيه بر اين راهبردها اقدامات مفيدترى انجام خواهند داد. محدوديتهاى مطالعه حاضر شامل عدم استفاده از مربيان زن و عدم كنترل رتبه

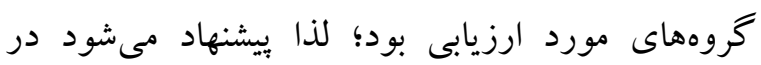
مطالعات آينده اين موارد مورد توجه قرار گيرد. سياسگز ارى يثزوشش حاضر تحقيق مستقل يثوهشى است و مورد تائيد

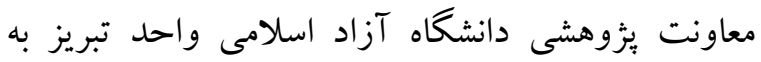


Journal of Physical Education and Sport (JPES), 12(3):343-349.

Maslach C. (2001). Job Bumout. Annual Review of Psychology:1-22.

Nafian S, Moradi M, Shams A. (2016). Relationship between Bumout with Self-Sfficacy among Super League Coaches in Selected Sports. Sport Psychology Studies, 4(14):98-79. (In Persian)

Nixdorf I, Beckmann J, Nixdorf R. (2020). Psychological Predictors for Depression and Burnout Among German Junior Elite Athletes. Frontiers in psychology, 11,601: 113.

PilHa J, King K, Dylan JD. (2011). The impact of bumout on work outcomes among South Korean physical education teachers. Journal of Sport Behavior, 34, 343-358.

Purcell R, Gwyther K, Rice SM. (2019). Mental Health In Elite Athletes: Increased Awareness Requires An Early Intervention Framework to Respond to Athlete Needs. Sports Med Open, 5,46:1-8.

Rasafiani M, Sahaf R, Shams A, Vameghi R, Zareian H, Akrami R. (2020). Validity and Reliability of the Persian Version of the World Health Organization Quality of Life Questionnaire the Older Adults Edition. Salmand: Iranian Journal of Ageing. 15(1):28-41.

Ryff CD, Singer BH, Love GD. (2004). Positive Health: Connecting well-being with biology. Philosophical Transactions of the Royal Society of London, 359:1383-1394.

Shams A, Nobari H, Afonso J, Abbasi H, MainerPardos E, Perez-Gomez J, Bayati M, Bahrami A, Carneiro L. (2021). Effect of AerobicBased Exercise on Psychological Well-Being and Quality of Life Among Older People: A Middle East Study. Front Public Health, 6;9:110.

Tashman LS, Tenenbaum G, Eklund R. (2010). The effect of perceived stress on the relationship between perfectionism and burnout in coaches. Journal of Anxiety, Stress, \& Coping, 23(2):195-212.
Vaez Mousavi M, Shams A. (2017). Mental Health of Iranian Elite Athletes. Iran J Health Educ Health Promot, 5 (3):191-202. (In Persian)

Volker R. (2010). Bumout, Coping and job satisfaction in service staff treating Opioid addicts - from Athens to Zurich. Stress and health, 26:149 159. 